\title{
A continuidade punitiva na \\ história do Brasil: \\ da era colonial à \\ redemocratização
}

\section{Larissa Cabelo de Campos*}

DOI: 10.11606/issn.2318-8855.v10i1p132-162

Resumo: Buscou-se investigar quais fatores contribuíram para a formação de uma cultura punitiva que levou o Brasil a adotar uma política penal de encarceramento em massa, fazendo-o figurar as primeiras posições entre os países que mais prendem sua população. A análise realizou um levantamento dos processos históricos que culminaram neste cenário, desde a colonização até o período imperial, bem como as duas ditaduras que marcaram o País. Concluiu-se que a construção do pensamento punitivo é um processo de continuidade que perpassa toda a formação do Estadonação. Constatou-se, dessa forma, uma divisão histórica de grupos sociais, em que há um reforço ideológico da separação de indivíduos entre "merecedores" e "não merecedores".

Palavras-chave: Autoritarismo, Escravismo, Punitivismo, Militarismo, Neoliberalismo.

\footnotetext{
* Larissa Cabelo de Campos é graduada em jornalismo e estudante de história na FFLCH. O presente artigo é fruto de pesquisa desenvolvida sob a orientação de Laurindo Dias Minhoto, professor do departamento de sociologia.E-mail para contato: larissacabelo.c@usp.br.
} 


\section{artigos}

\section{A continuidade punitiva na História do Brasil}

\section{Introdução}

O Brasil ocupa o terceiro lugar no ranking de países com o maior número de encarcerados: são 755 mil pessoas privadas de liberdade nas instituições penais brasileiras segundo levantamento realizado pelo Infopen (PRESOS..., 2019). Para compreender quais fatores levaram o País a se tornar um dos líderes em encarceramento em massa1, é necessário, no entanto, olhar para o passado, assim como para os processos neoliberais que se estabeleceram mundialmente e seus impactos nas instituições nacionais.

A crise do Estado de bem-estar deu lugar a um novo sistema políticoeconômico: o neoliberalismo. Nesta mudança, o ideal de reabilitação que pairava no welfarismo tende a ser substituído pela visão de que a prisão é estritamente necessária como ferramenta de castigo.

Se no welfarismo penal a prisão sai do centro da sociedade a ponto de Foucault, em Vigiar e Punir, prever sua gradativa retração, no controle do crime na sociedade neoliberal contemporânea ela volta a figurar socialmente como a principal forma de castigo e de controle de corpos.

É neste contexto que Wacquant (2007) levanta o debate sobre o paradoxo do neoliberalismo: um sistema em que o Estado se retrai no front econômico e social e se intensifica no campo punitivo. Retração que, por sua vez, tem como consequência a desregulamentação do mercado de trabalho e uma queda na segurança social. A mão econômica que oprime e que exclui uma parcela da população e que, diretamente, cria a insegurança social e a criminalidade é irmã da mão penal que

\footnotetext{
1 Segundo Garland (2001), o encarceramento em massa se constitui sobre dois fundamentos: o primeiro é o número exorbitante de encarcerados; o segundo é a prisão sistemática de grupos de pessoas caracterizados, em sua maioria, pela raça e pela classe.
} 


\section{artigos}

\section{Larissa Cabelo de Campos}

pune e castiga pelo crime cometido; as duas pertencem ao Estado.

Wacquant (2007) afirma que o aparelho carcerário brasileiro é marcado pelas superlotações que mais parecem campos de concentração ou calabouços feudais. "O sistema penitenciário do Brasil efetivamente ostenta os defeitos das piores cadeias do Terceiro Mundo, numa escala digna do Primeiro Mundo, devido a seu tamanho absoluto, a seu enraizamento urbano e à persistente indiferença dos políticos e do público" (WACQUANT, 2007, p. 208).

A expansão do braço penal do Estado serve para conter a camada excluída pelo sistema, além de passar a imagem de efetivo combate ao crime urbano. No caso brasileiro, Wacquant (2007) ressalta que a importação das políticas penais norteamericanas se torna ainda pior pois o seu passado colonialista, escravagista e marcado por duas ditaduras intensifica a violência policial.

Tanto Wacquant quanto Garland apontam a crise do Estado de bem-estar e a sua transformação em neoliberalismo como os principais fatores para o crescimento e a consolidação do encarceramento em massa - principalmente nos países europeus. No entanto, o Brasil não viveu a experiência institucional de um Estado de bem-estar social plenamente consolidado. Para compreender quais os fatores levaram o País a adotar esta política penal, será necessário retomar alguns processos históricos e sociais.

\section{Sociedade punitivista: continuidade e permanência}

O Brasil é um país com um passado autoritário e repressivo, cultura essa que respinga na contemporaneidade: uma sociedade punitivista semeada em suas raízes históricas. Como apontado por Schwarcz (2019), a escravidão não foi apenas um sistema econômico, foi além: marcou as condutas da sociedade brasileira e 


\section{artigos}

\section{A continuidade punitiva na História do Brasil}

determinou marcadores de classe e de raça.

A seguir, serão apresentados aspectos de algumas das mais importantes análises sobre a cultura da violência e da punição no país com o objetivo de identificar as influências do passado na construção contemporânea do pensamento punitivo brasileiro e da consolidação do encarceramento em massa como política do Estado.

Tão presente no cotidiano contemporâneo, seja na realidade, seja no imaginário formado pelo medo, a violência foi a base para as dinâmicas sociais escravocratas em que um grupo detém o poder não apenas de explorar o trabalho, como também de possuir a pessoa que o produz. A violência se insere "na subjugação de uma raça à outra, na coisificação social do trabalhador" (MACHADO, 1987, p. 17) e na força protetiva do sistema dominante.

Os povos trazidos ao "Novo Mundo" para serem escravizados eram reduzidos a um objeto, uma ferramenta, e, como um objeto, outro indivíduo o possuía. Há o que podemos chamar de "não humanização": os africanos e seus descendentes, escravizados ou libertos, não eram vistos como seres possuidores de alma. Desde o Brasil Colônia, permeando o período imperial, é possível observar uma divisão na categoria das pessoas: nós, os brancos civilizados; eles, os indígenas que necessitam de Deus e da civilização; e os outros, os negros escravizados que, por não serem possuidores de alma, não têm nem mesmo a chance de salvação. Posteriormente, divisão parecida pode ser observada na teorização de Garland (2001) sobre a criminologia do outro.

O que se estabelece no período é uma sociedade não apenas baseada na violência, mas uma rede de controle social que utiliza instrumentos além da força 


\section{artigos}

\section{Larissa Cabelo de Campos}

para se manter - a vigilância, por exemplo, um dispositivo fundamental para a dinâmica.

O exemplo do furto, utilizado por Machado (1987), ajuda a compreender como a vigilância se estendia para a sociedade: o fato de um escravo utilizar dinheiro no comércio era suspeito aos olhos da população branca, levantando a possibilidade de que o dinheiro fosse fruto de roubo ou furto. Há casos de escravizados que recebiam algum tipo de pagamento de seus senhores e conseguiam se livrar de processos ao provar a origem do dinheiro.

Outros tipos de vigilância também ocorriam no domínio doméstico, dentro das fazendas. Havia uma "vigilância constante" para estabelecer a disciplina, e afirmava-se que o melhor aproveitamento do trabalho forçado era constituído "no olho do senhor e no chicote do feitor, para docilizar o corpo do escravo e adaptá-lo ao mundo do trabalho" (MACHADO, 1987, p. 63).

Na prática, para se extrair o máximo de trabalho de um indivíduo - muito acima do que o corpo poderia suportar -, eram utilizadas penitências físicas em formas de castigo. Ainda que, em algumas situações, a punição fosse combinada a um sistema de recompensa, a agressão física era a principal ferramenta empregada. “Disciplina e vigilância resultaram, nas grandes unidades produtivas, na constituição de uma pedagogia da violência baseada na estrita obediência" (MACHADO, 1987, p. 86).

Por todo o período colonial e imperial, houve a disseminação de "manuais" que pretendiam ensinar aos senhores as melhores técnicas de castigo aos escravizados. 0 castigo é, portanto, utilizado como manutenção da ordem, representando o arbítrio e o mandonismo que marcaram os primeiros séculos de formação da nação. E o 


\section{artigos}

\section{A continuidade punitiva na História do Brasil}

domínio de um grupo sobre outro se naturalizava, assim, em tal sociedade caracterizada pela autoridade do Senhor (SCHWARCZ, 2019, p. 45).

O punitivismo já se enraizava como meio de impor submissão a um grupo social - neste caso, caracterizado pela etnia. Há, neste período, a definição da "noção de raça social", ou seja, quando o conceito de raça é definido - e criado - pela cultura e pelo sistema social vigentes (SCHWARCZ, 2019, p. 32). É interessante se atentar ao detalhe de que a vigilância, aliada ao punitivismo, era característica da rede de controle estabelecida no período. Dessa forma, é importante destacar que, assim como relembrou Schwarcz (2019), tais padrões não se encerram com trocas de regime, mas ficam enraizados nos costumes e nas crenças.

No entanto, a arbitrariedade também atinge o homem branco e pobre. Franco (1997) analisa na civilização agrária do século XIX, nos estados de São Paulo e Rio de Janeiro - que ela define como "mundo caipira" -, as relações da sociedade escravocrata com o homem livre e pobre, indivíduo que permaneceu à margem da produção mercantil.

Em tal organização social, o escravo era majoritariamente a mão de obra das grandes produções agrícolas, e, como consequência, houve a formação de um grupo social que não estava alocado no trabalho assalariado, mas que também não era proprietário de terras. As funções delegadas a esse grupo eram, basicamente, as que não poderiam ser ocupadas por escravos.

A partir de então, há a definição do estereótipo de "ralé": o homem que não havia se "proletarizado" e que não compunha os processos e as estruturas de tal sociedade. Nessa organização, a marginalização socioeconômica produz um "tipo social" que seria conhecido como o "caipira preguiçoso", a figura do indivíduo não 


\section{artigos}

\section{Larissa Cabelo de Campos}

alocado nos processos de produção.

Por todo o corpo social, as relações no "mundo caipira" eram permeadas pela violência institucionalizada como padrão de comportamento: seja na solução de problemas, ocasionada por discussões acaloradas, como demonstração de "coragem e valentia"; seja na forma de fazer "justiça" - e o público, geralmente, se entrelaçava ao privado. As agressões estavam incorporadas tanto nos vínculos familiares quanto na vizinhança e no âmbito público.

Há, portanto, uma naturalização desse comportamento, e nesse contexto a comunidade tem a violência como um código de conduta socialmente construído, estabelecido e legitimado entre os homens livres e pobres, mas também entre os fazendeiros e homens de posse.

A partir de processos criminais, Machado (1987) analisa as dinâmicas estabelecidas no regime escravista entre 1830 até o seu fim, em 1888. Os registros são fruto da mudança nas relações penais dentro do sistema, visto que o judiciário passa a agir como mediador nos conflitos entre senhores e escravos - prática pouco comum até então, visto que tais conflitos eram resolvidos no âmbito doméstico.

A justiça não tem um papel neutro, ela é utilizada como uma aliança com o poder particular para auxiliar na manutenção da dominação escravista. As revoltas escravas causavam temor no poder senhorial - situação agravada após a Revolta dos Malês -, que buscou na justiça uma forma de conter e reprimir esses levantes (MACHADO, 1987). Portanto, por mais que causasse certo incômodo a "intromissão" do Poder Judiciário no perímetro doméstico dominado pelos senhores, não há conflitos de interesse entre as duas forças. Pelo contrário, o sistema de justiça auxiliará a classe dominante a acalmar seus temores. O aparelho estatal, portanto, 


\section{artigos}

\section{A continuidade punitiva na História do Brasil}

era utilizado em nome dos interesses pessoais de grupos dominantes e essencialmente como um poderoso instrumento de dominação.

Fruto da organização do Novo Estado, a Constituição, bem como o Código Criminal de 1830 e o Código de Processo Criminal de 1832, abolem as penas de açoites e torturas. Porém, essa mudança não se estendia aos escravos, e o único artigo que faz referência a eles determinava que, quando não fossem condenados à morte ou às galés, suas penas seriam comutadas em açoites (KOERNER, 2006).

A lei de 10 de junho de 1835 é sancionada como uma ferramenta para amparar os senhores, defender a instituição escravista e ser um instrumento de manutenção de poder. A lei oficializou o "castigo" aos escravos que insurgissem contra seus senhores ou suas famílias, condenando-os à pena de morte. Apesar de o aparato jurídico escravocrata determinar a nulidade jurídica do escravo (MACHADO, 1987), uma categoria à parte dos cidadãos e que apenas se aproximava de um agente social quando se tornava um réu passível de punição, ele ainda não era submetido ao mesmo sistema que os indivíduos livres.

Construída em 1872 para atender exigências de humanização previstas na Constituição, a Casa de Correção da Corte (CCRJ) é mais um aspecto do contexto: pensada à luz dos ideais iluministas, na prática ela foi estruturada mais para manter as relações sociais vigentes e para servir como uma ferramenta de controle do corpo do que para oferecer um meio de recuperação (BANDEIRA apud KOERNER, 2006)

Novamente, quando é feito um recorte racial, a situação torna-se mais crítica. Enquanto brancos livres ocupavam andares intermediários com melhor estrutura e limpeza, negros - tanto escravizados quanto livres - eram designados aos andares inferiores, caracterizados pela insalubridade e pela falta de higiene. Além disso, 


\section{artigos}

\section{Larissa Cabelo de Campos}

também eram obrigados a realizar os serviços de limpeza e a prestar obediência aos outros detentos (KOERNER, 2006).

As estruturas sociais que existiam fora dos muros da prisão eram, de certa forma, reproduzidas entre os presos, tendo o negro ocupado a posição de "servir" indivíduos que, na prática, haviam violado o mesmo sistema penal. O cerne da política de exclusão já estava presente na estrutura da CCRJ e nos códigos penais.

Nas ruas, as relações eram semelhantes: a polícia prendia sistematicamente indivíduos suspeitos. O que caracterizava, então, um suspeito? Nas palavras de Koerner (2006):

Os indivíduos negros ou pardos eram antes de tudo suspeitos, e a polícia os detinha com o objetivo de verificar se eram escravos. O controle manifestavase de diversas formas, como as rondas noturnas, que detinham sem maiores explicações negros que circulavam na cidade após o toque de recolher, os regulamentos sobre o porte de armas, a venda de bebidas alcoólicas, a proibição da prática da luta de capoeiras. (KOERNER, 2006, p. 15).

Se antes a falta de uma ocupação formal era motivo para uma eventual prisão, o senso comum contemporâneo não diverge desta visão: a "vagabundagem" e a falta de vínculo empregatício auxiliam na construção demonizada do estereótipo do criminoso, o não trabalhador.

Ao analisar as instituições de segurança no Brasil, assim como na América Latina de colonização ibérica, constata-se que a força militar não tem como missão a proteção do território e do Estado. Seu objetivo principal é servir ao Estado e combater o inimigo interno, materializado em determinados perfis de seu próprio 


\section{artigos}

\section{A continuidade punitiva na História do Brasil}

povo. Oscilando as características do grupo alvo dessa "guerra" - sendo em alguns momentos definidos pela cor e em outros pela classe social -, o militarismo foi escolhido como política institucional e tem se mantido como tal (TEIXEIRA, 2014).

A palavra "vigilância" aparece constantemente na análise de Cancelli (1994) sobre o período da Era Vargas. Ela é um elemento chave na manutenção do poder do ditador, assim como a censura, a perseguição e a tortura. Nesse processo, a polícia é a peça fundamental na instrumentalização do poder, do controle do Estado e da legitimação da violência.

A criação dos "inimigos da nação" será essencial para a justificativa de tais ações autoritárias: elege-se perfis determinados que devem ser combatidos a qualquer custo. Na Era Vargas, os inimigos principais eram os comunistas e os estrangeiros, mas o "jeca", ligado ao homem do campo, também entrou na mira do sistema. O temor aos primeiros é construído com discursos oficiais abertamente anticomunistas, tendo tal visão sido reforçada por uma ideologia cristã que denominava o comunismo como “obra do demônio" (CANCELLI, 1994, p. 80).

Há o perfil do "Homem Novo", idealizado pelo regime, em que o indivíduo é regenerado pelo trabalho, possui determinado tipo físico e se enquadra em um só perfil racial (CANCELLI, 1994, p. 24). Na outra ponta, há tudo o que não se encaixa nesse perfil, os "não merecedores": os desempregados, os comunistas, os não brancos, os estrangeiros. Tudo o que foge à regra deve ser combatido e, por vezes, eliminado.

A construção do perfil desses inimigos ainda ganha uma nova ferramenta: a institucionalização da Antropologia Criminal. É a utilização da ciência para propagar ideais racistas e eugenistas, que afirmam que o desvio de comportamento se dá por 


\section{artigos}

\section{Larissa Cabelo de Campos}

características sociobiológicas. A partir disso, surge um novo modelo de atuação, com embasamento racista, em que o combate não deve ser ao crime, mas ao sujeito da ação.

Neste contexto, há a propagação da imagem do criminoso como “um indivíduo anormal, uma variedade do gênero humano" (CANCELLI, 1994, p. 78). É um processo de demonização do indivíduo que comete um crime. Em um Congresso Policial de 1936, o termo "expulsão de alienígenas" foi amplamente utilizado para se referir aos estrangeiros (CANCELLI, 1994, p. 123).

Ainda que a história denuncie padrões de continuidade desde o sistema escravocrata na utilização da violência como manutenção de poder (SCHAWRCZ, 2019, p. 157), foi no governo de Vargas, no entanto, que houve uma grande mudança na atuação da polícia: ela se torna centralizada na figura do governante e politizada. O último item será ponto importante para o papel que a instituição terá nos anos subsequentes: com a interferência direta do presidente, novos caminhos de controle e repressão se abrem. A Era Vargas marca a fundação de novas formas de controle social.

Há uma utilização das forças policiais deliberadamente sem limitações legais. É neste período também que a instituição policial passa a ocupar um espaço em que se coloca acima da lei. Vigilância da sociedade como um todo, tortura e prisões sem condenações se tornarão constantes. A polícia "escolhia os novos inimigos a serem perseguidos e seguia, às cegas, as diretrizes impostas por Getúlio Vargas" (CANCELLI, 1994, p. 215).

O projeto político desse regime autoritário previa um aparato policial que promovesse o controle social, a disciplinarização dos trabalhadores - e da sociedade 


\section{artigos}

\section{A continuidade punitiva na História do Brasil}

como um todo - e a constante negação da individualidade dos cidadãos (CANCELLI, 1994, p. 26).

Tal politização das forças policiais não acabaria simplesmente com a queda do regime, nem sem uma ruptura no sistema vigente. O que será observado é o reforço da utilização dessas instituições como controle da sociedade sempre que for "necessário" ao Estado.

A Comissão da Verdade do Estado de São Paulo "Rubens Paiva" dedicou um capítulo de seu relatório oficial para discutir a militarização da segurança pública após o golpe de 64. A característica de aparelho bélico do Estado é dada às forças policiais nacionais, que desempenham um papel de instrumento governamental como controle de sua população, tratada como um inimigo interno. Duas são as formas em que essas forças são utilizadas: jogar indivíduos dentro do terceiro maior sistema penal em números de encarcerados ou, simplesmente, executar grupos sociais (COMISSÃO, 2015).

A Doutrina de Segurança Nacional se torna lei em 1967 com o decreto $n^{\circ}$ 314, e assim a ideia de um inimigo interno, que necessita ser combatido, é oficializada e institucionalizada. A ditadura pode não ter criado a violência e a repressão a serviço do Estado, mas ela foi fundamental para qualificar e intensificar essas práticas, de modo que elas fossem permitidas e garantissem os interesses da classe dirigente. A utilização da Polícia Militar como ferramenta de repressão foi uma escolha política para preservar a ordem pública conservadora - para essa instituição, a manutenção da ordem é prioritária, deixando em segundo plano a prevenção à violência (COMISSÃO, 2015).

A Polícia Civil e, principalmente, a Polícia Militar foram instituições elementares 


\section{artigos}

\section{Larissa Cabelo de Campos}

durante o regime militar - além de servir como um de seus braços repressivos. O Esquadrão da Morte do estado de São Paulo, que ficou conhecido pela execução sumária promovida por policiais civis entre 1968 e 1971, pôde existir - com sua força e extensão - devido à legitimidade dada à violência durante a ditadura. É sintomático que o homem à frente do Esquadrão tenha sido um braço direito do regime: Sérgio Paranhos Fleury dirigiu o Departamento de Ordem Política e Social (DOPS) e o Destacamento de Operações de Informação - Centro de Operações de Defesa Interna (DOI-CODI) e foi responsável por um complexo sistema de repressão e de tortura a presos políticos (TEIXEIRA, 2014). A figura de Fleury é uma boa representante das forças policiais deste período autoritário: ao mesmo tempo em que servia como o carrasco dos presos políticos, atuava também no extermínio de civis e de "criminosos comuns".

No caso da Polícia Civil, havia um descrédito crescente quanto à instituição devido a casos extremos de corrupção e de envolvimento com o crime. Esse foi o contexto que precedeu a criação da PM. Apesar do enfraquecimento como instituição, a Polícia Civil também serviu como aparato do governo militar.

A criação da Polícia Militar em 1969 por meio do Decreto-lei federal n 667 foi um ponto decisivo para a utilização da força policial como aparato repressor. Submetidas ao Exército nacional, ou seja, concebidas em uma lógica de guerra, uma forte militarização é imprimida na segurança pública.

A ROTA - Rondas Ostensivas Tobias de Aguiar, uma tropa especial do Comando Geral da Polícia Militar do Estado de São Paulo - vai se configurar como a organização por excelência símbolo da violência extralegal da Polícia Militar. Concebida pelo regime militar para enfrentar a resistência armada com força truculenta e letal, ela 


\section{artigos}

\section{A continuidade punitiva na História do Brasil}

não desaparece após a revogação do Al-5, apenas passa por uma reformulação e permanece servindo para a repressão, seja da "criminalidade comum", seja contra militantes e manifestantes - ainda que em uma democracia. Tanto dentro de uma ditadura quanto dentro de uma democracia, a ROTA é concomitantemente aplaudida, temida e prestigiada pela população paulista: uma garantia de impunidade (TEIXEIRA, 2014). A legitimação de sua atuação ilegal é dada, então, não apenas pelo regime, mas pela própria sociedade.

Para demonstrar a força de repressão que a polícia militar brasileira representa, Wacquant (2007) destaca a diferença abismal entre os números de mortos pelas mãos das polícias militar paulista e nova-iorquina. Os agentes norteamericanos mataram 24 civis no ano de 1992, no mesmo período a polícia paulista matou 1.470 pessoas -4 por dia.

Belli (2004) lembra que, com o fim do regime militar, contava-se que o Estado Democrático de Direito seria estabelecido e estruturado, algo que, no entanto, não se estendeu às classes baixas. Os acontecimentos que se sucederam (e que se sucedem) apenas apontou para uma permanência no padrão de políticas sociais e de segurança, jogando-os ainda mais à margem, prendendo e matando sistematicamente conforme classe social e características raciais.

A ditadura intensificou, legitimou e institucionalizou uma prática militarista existente desde o período colonial; no entanto, o ímpeto punitivista alocado no cerne da sociedade brasileira não foi interrompido com a redemocratização. Ironicamente, foi a partir dos anos 1990 que houve um aumento expressivo no número de encarcerados.

O início da transição para a democracia, no fim da década de 1970 e no começo 


\section{artigos}

\section{Larissa Cabelo de Campos}

da de 1980, foi marcada por uma ascensão do debate pelos direitos civis, pela mobilização para libertar presos políticos e pelo questionamento sobre as cadeias nacionais, a tortura e a seletividade penal. De forma inédita, entram em cena questões sobre as prisões e sobre a coerção do Estado.

Enquanto outros países enfrentam a crise do welfare state e do "ideal ressocializador", o Brasil passa pelo breve período em que o preso é reconhecido como um sujeito de direitos. Teixeira (2009) afirma que as violações de direitos humanos durante a ditadura militar prejudicaram como, no futuro, iríamos lidar com as questões sociais e carcerárias. O discurso ressocializador não se tornou hegemônico, pois no passado não encontrou terreno fértil para fincar raízes. 0 regime não apenas manchou a história, como deixou uma ferida aberta e exposta.

É necessário pontuar a lembrança de Serra (2014) sobre a não linearidade da transição para a democracia, além de certas rasuras jurisdicionais na própria Constituição de 88. É inegável o avanço democrático alcançado com a Constituição, no entanto, o art. $5^{\circ}$ vai equiparar o tráfico de drogas com crimes hediondos e terrorismo (TEIXEIRA, 2009). Veremos posteriormente o impacto que essa equiparação terá na expansão da população prisional no Brasil.

\section{O pensamento punitivo na contemporaneidade}

Após uma breve retomada histórica sobre a utilização da violência como mecanismo de controle em diversos períodos, serão levantados pontos sobre como os mecanismos de controles contemporâneos atuam na sociedade neoliberal em conjunto com as influências herdadas do passado.

Garland (2001) aponta que a maior mudança, a partir do populismo penal, no campo da cultura do controle foi uma nova forma de pensar a vítima (que passa a ser 


\section{artigos}

\section{A continuidade punitiva na História do Brasil}

uma figura central, com redes de apoio e potencialização da voz) e o criminoso (que passa de indivíduo a ser regenerado ao complexo de monstro).

Os infratores sob livramento condicional, liberdade vigiada e juizados de menores agora são menos representados no discurso oficial como cidadãos socialmente marginalizados que necessitam de apoio. Ao contrário, eles são retratados como indivíduos culpáveis, não merecedores e perigosos, que devem ser cuidadosamente controlados para a proteção do público e para a prevenção de outros crimes (GARLAND, 2001, p. 175).

A ressignificação na forma de pensar o crime e o criminoso é exemplificada pelo papel da vítima: quando ela passa a figurar as discussões, a ressocialização do criminoso é colocada de lado. A partir desse momento, a forma de controle do crime - e do indivíduo que o comete - muda, a reabilitação sai de cena e a prioridade é o controle situacional, de modo que os custos sejam mínimos e a segurança seja máxima.

No entanto, o autor compara o posicionamento com a realidade: a guerra ao crime é custosa e não produz efeitos significativos na segurança pública. A lógica de guerra, por si só, derruba a racionalidade econômica (GARLAND, 2001). O aumento das penas privativas de liberdade, bem como os custos com a literal guerra ao crime, serve para responder aos anseios da população por "respostas rápidas". No entanto, essa prática atua, principalmente, como escudo político ao fornecer esse retorno imediato à sociedade.

A ascensão da figura da vítima para o ponto central da discussão é de importância para a compreensão sobre como esse pensamento se solidifica e se enraíza em uma sociedade. A vítima passa a ser papel central das novas criminologias 


\section{artigos}

\section{Larissa Cabelo de Campos}

- mais populistas - e ocupa o lugar de análise antes ocupado pelo indivíduo que cometia um crime (GARLAND, 2001). No entanto, isso se dá em um contexto em que essa figura é utilizada como um motivo para a punição, um bode expiatório para a vingança e, muitas vezes, como elemento eleitoreiro. A dinâmica fortalece um sistema que não busca encontrar alternativas para diminuir a incidência de crimes.

Wacquant (2007) aponta, ainda, a divisão entre os pobres "merecedores" e os "não merecedores" feita pela mesma elite política que pune, que legisla, que detém o poder. A divisão se dá entre os que "merecem ser salvos e inseridos no trabalho assalariado" (WACQUANT, 2007), enquanto os "não merecedores", excluídos do mercado de trabalho, são impelidos a adentrarem nos setores ilegais da economia. Indivíduos inclusos na segunda categoria, incorporados ou não na "economia de rua", são colocados à margem, excluídos e, não dificilmente, eliminados.

Quando olhamos para as bases da prisão, a visão que temos não é diferente. Há uma diferenciação entre classes de indivíduos, de maneira que não há como conceber um modelo que não seja necessariamente excludente, visto que a passagem pelo encarceramento altera diretamente a vida dos indivíduos, deixando marcas sociais dificilmente reversíveis - ao deixar de ser um preso, ele passa a ser um egresso.

É dessa forma que podemos enxergar na prática a afirmação de Foucault sobre a missão da prisão de instaurar uma oposição entre a plebe proletarizada e a não proletarizada (TEIXEIRA, 2009) - tese que conversa com a divisão entre "merecedores" e "não merecedores" estabelecida por Wacquant (2007).

Os pobres "não merecedores" são determinados como um problema para a sociedade. São delimitadas subcategorias desse setor marginalizado: dependentes da 


\section{artigos}

\section{A continuidade punitiva na História do Brasil}

assistência social, ociosos, moradores de rua, dependentes químicos, delinquentes e os deliberadamente criminosos. Ao retomar o passado, é possível encontrar a categoria dos "não merecedores" nas figuras do "vadio", do "caipira preguiçoso", do desocupado.

Belli (2004) discorre sobre a construção histórica do perfil do delinquente: o negro, o pobre, o favelado. O autor incorre, ainda, sobre o erro de ligar a criminalidade diretamente à pobreza: a relação não é mecânica, bem como não é direta. Ao se estabelecer essa relação, caminha-se pelo discurso de que há um perfil do crime. No entanto, os chamados "crimes de colarinho branco" são o exemplo de que a transgressão está presente em todas as classes, mesmo que os pesos punitivos sejam diferentes.

A demonização do indivíduo que comete um crime torna-se, então, uma justificava para os excessos e as injustiças policiais. Um ato delituoso passa a justificar sessões de tortura, perseguições e mortes se a "finalidade" for o bem comum e o combate ao crime. É a naturalização de uma nova divisão na sociedade: a dos cidadãos de bem e a do delinquente que deve ser contido.

O criminoso é, assim, "demonizado", considerado um caso perdido e sem a mínima chance de ressocialização. Torturá-lo para obter informações quando não como mecanismos de extorsão - ou matá-lo justifica-se pela simples razão de que, ao ter se bandeado para o lado do crime, adentrou o campo de batalha, tornou-se inimigo, transmutou-se em agente da destruição da sociedade, enfim, submeteu-se ao rigor dos agentes da ordem. Não se trata de uma doutrina formal, mas de um conjunto de opiniões e predisposições que tendem a legitimar a ação ilegal da polícia como um instrumento de combate à criminalidade violenta. (BELLI, 2004, p. 21).

Portanto, o senso comum sustenta a visão de que os abusos policiais são 


\section{artigos}

\section{Larissa Cabelo de Campos}

a única forma de deter a criminalidade. Esse monstro criminoso, um ser sem sentimentos nem empatia, seria incapaz de mudanças, e, sem tais mudanças, a única saída seria a literal guerra contra essa personificação do mal. Alba Zaluar (apud BELLI, 2004) aponta que o treinamento policial permanece tendo como alvo principal o controle e as repressão aos moradores das favelas - classe que compõe o estereótipo de setor perigoso da sociedade brasileira. A letalidade policial não apenas se sustenta pelo senso comum, ela é um reflexo da hierarquia social.

Davis (2003) usa um termo cunhado por George W. Bush para descrever como se define o conceito do senso comum sobre a prisão: um lugar de "malfeitores" sendo o estereótipo dos "malfeitores" diretamente ligado ao negro em um contexto norte-americano, e que não é distinto do brasileiro. Na prática, a prisão é um espaço que serve a um preceito ideológico, no qual os "indesejáveis" são descartados para deixarem de ser um problema (DAVIS, 2003).

Teorizada por Garland (2001), a criminologia do outro é composta na prática por um pensamento antimoderno e antissocial, mas ela também passa a ideia de anticiência, visto que ignora os dados, os fatores sociais e as análises criminológicas e anda pelo caminho do revanchismo e do punitivismo como instrumento de vingança. Não há interesse em evitar que o crime aconteça, há a necessidade de punir quem o comete - e muitas vezes também quem não o comete, na ânsia de encontrar um culpado.

Nas palavras de Serra (2014), o que ocorre nesse processo é uma sacralização da pena, contexto em que a punição é tida como a solução de todos os problemas, inclusive os sociais, e em que a opinião pública clama constantemente por mais punições. Se considerarmos que a prisão é a penalidade por excelência, sendo a regra 


\section{artigos}

\section{A continuidade punitiva na História do Brasil}

e não a exceção, a sociedade não clama apenas por mais punição, ela clama diretamente e indiretamente - por mais prisões.

É esta a criminologia que justifica o movimento de encarceramento em massa em um sistema que condena, mas não busca evitar o crime. Se não há um retorno no sentido de impacto nas taxas de criminalidade, qual motivo sustenta a punição pela punição? Segundo Garland (2001), o método centra-se na manutenção da ordem e da autoridade - o que não é sinônimo de segurança -, na valorização de padrões morais e de tradição e no reforço do senso comum.

No entanto, mais profundo que isso, há uma manipulação na concepção da imagem de indivíduos na sociedade, como um método psicológico que constrói a identidade do "outro": o outro é quem comete o crime, o outro é uma ameaça, o outro é o culpado por todos os males, a natureza do outro é ruim, o mal é intrínseco, o outro - e não eu - deve ser punido. O outro, portanto, não é merecedor como eu sou. Compreender o outro seria humanizá-lo e, consequentemente, nos enxergar neles (GARLAND, 2001), prática que não é conciliável com a divisão cultural entre "nós" e "eles".

O Estado punitivo vai se respaldar em uma lógica que elege o "Outro enquanto inimigo e então, diante deste olhar, este Outro personifica-se enquanto aquele, que merece, portanto, ser punido" (SERRA, 2011, p. 2). Sob a retórica da guerra (ainda que vivendo em tempos de paz, em teoria), tudo se torna aceito para derrotar o inimigo, e é essa perspectiva que permeará, de formar transversal, toda a organização do Estado brasileiro para além das forças de segurança.

Garland (2001) também discorre sobre o papel da mídia na desinformação e na criação de mitos sobre o crime e o criminoso por meio da dramatização da vingança. 


\section{artigos}

\section{Larissa Cabelo de Campos}

Os programas televisivos sobre o tema ganharam popularidade, e o crime está constantemente retratado em obras cinematográficas, reforçando estereótipos e contribuindo para a exclusão de determinados perfis.

No Brasil, programas sensacionalistas e policialescos já estavam presentes nas rádios da década de 1970, mas é o “Aqui Agora”, estreado em 1991 no SBT, o pioneiro do gênero na televisão. Atualmente, programas como o "Cidade Alerta”, da Record, e o "Brasil Urgente", da Rede Bandeirantes, denunciam os males das cidades brasileiras diariamente na televisão aberta (RIBEIRO, 2016).

O terror e o medo são manipulados para servir de alimento para a sensação de insegurança constante entre a população. A demonização do indivíduo que comete um crime é elemento cotidiano no conteúdo divulgado por esses programas.

Wacquant (2007) chama esse processo de pornografismo da segurança, ou seja, a exploração de um medo construído pela mídia e pelo discurso político, levado ao extremo de forma deliberada e teatral, e que reduz o trabalho pela diminuição da criminalidade a um "espetáculo ritualizado, que só serve para alimentar as fantasias de ordem do eleitorado e reafirmar simbolicamente a autoridade viril de quem toma as decisões no âmbito do Estado" (WACQUANT, 2007, p. 467).

Juntamente com a mídia, personalidades políticas também auxiliam na reafirmação de um discurso alarmista, escatológico e, consequentemente, punitivo. Este medo do crime, segundo Garland (2001), gera um estigma que recai sobre o homem negro e jovem que carrega o estereótipo de criminoso e de estranho perigoso. A exclusão, portanto, tem também dimensão cultural e está devidamente inscrita no imaginário popular, tendo uma de suas raízes em nosso passado escravocrata. 


\section{artigos}

\section{A continuidade punitiva na História do Brasil}

Se o processo de formação do Estado Nacional interferiu na forma de se punir e de se pensar o crime no País, no cenário contemporâneo essa herança se combinou com a expansão da política neoliberal - que atingiu até mesmo os países de capitalismo periférico que nunca tiveram o welfare state, como é o caso do Brasil.

Assumir o modelo neoliberal é, também, tirar a responsabilidade do Estado sobre a prática criminal (TEIXEIRA, 2009). A consequência observada é um Estado que não se ocupa em ressocializar e, muito menos, em buscar soluções para evitar o crime. A punição é sempre a saída mais fácil - e a mais escolhida.

Apesar de nunca termos passado por nenhuma fase de welfarismo penal ou por nenhuma reforma que priorizasse a ressocialização do indivíduo, é indispensável pensar que a nova configuração do sistema penal internacional influenciou políticas e práticas brasileiras. A importação das políticas norte-americanas de tolerância zero e da guerra às drogas são exemplos da influência externa sob o sistema nacional.

A política de Tolerância Zero é o modelo da nova criminologia conservadora e neoliberal: derruba-se a responsabilidade coletiva pela exclusão social, atribui a culpa apenas ao indivíduo e delega ao Estado - quase que exclusivamente - o dever de punição. O problema da violência urbana é reduzido de forma simplista a um caso de polícia (BELLI, 2000).

O resultado é um pensamento em que o transgressor não é fruto das relações sociais e de fatores externos sobre sua vida, como o seu passado e sua realidade social. Em vez disso, a culpa é individualizada e personificada. O objeto do problema deixa de ser a infração e passa a ser o infrator, processo que já ocorria no regime de Vargas. 


\section{artigos}

\section{Larissa Cabelo de Campos}

Esse processo mascara os problemas sociais que o Estado não resolve e reafirma a responsabilidade individual dos atos. Isso promove diretamente a irresponsabilidade coletiva sobre esses mesmos problemas (WACQUANT, 2007).

No entanto, como responsabilizar individualmente comportamentos frutos de dinâmicas coletivas? Se o desemprego atinge diretamente determinadas classes sociais e etnias, a marginalização é voltada a grupos definidos socialmente e o acesso a direitos básicos ainda é restrito a uma grande parcela da população, então, o local onde você nasce é determinante na trajetória de vida que você terá. Ou seja, a responsabilidade individual é questionável, afinal, não são apenas as escolhas pessoais que definirão o futuro do indivíduo.

A definição de Wacquant (2007) para a atual atuação do Estado no campo punitivo é de projeto político. O autor reafirma o caráter punitivo como ferramenta de controle dos problemas do próprio Estado: o que não se encaixa na estrutura previamente definida é sufocado e retirado de circulação. A construção da imagem do criminoso - ou a desconstrução, se pensarmos que o estereótipo retira sua cidadania - permanece sendo o principal pilar que sustenta o modo neoliberal de segurança pública.

A penalização serve aqui como uma técnica para a inviabilização dos "problemas" sociais que o Estado, enquanto alavanca burocrática da vontade coletiva, não pode ou não se preocupa mais em tratar de forma profunda, e a prisão serve de lata de lixo judiciária em que são lançados os dejetos humanos da sociedade de mercado. (WACQUANT, p. 21, 2007).

Um exemplo é a figura do traficante, personagem que protagoniza o atual 


\section{artigos}

\section{A continuidade punitiva na História do Brasil}

papel de inimigo na sociedade brasileira, fruto de uma guerra declarada ao uso e venda de substâncias ilícitas. $\mathrm{O}$ art. $5^{\circ}$ da constituição será elemento fundamental neste momento, pois, ao equiparar o tráfico de drogas a crimes hediondos - como homicídio e estupro de vulnerável -, ele valida o combate militar a este "inimigo interno".

A guerra às drogas não apenas legitima uma lógica militar contra a própria população, ela é um dos principais motivos para o alto número de encarcerados: mais de 200 mil estão encarcerados devido a tráfico, perdendo apenas para crimes contra a propriedade privada (QUANTIDADE..., 2019). O impacto da Lei de Drogas no estado paulista, sancionada em 2006, foi descomunal: o número de presos por tráfico aumentou 508\% em 12 anos (NÚMEROS..., 2018).

Seguindo a tendência norte-americana iniciada com Nixon, a questão das drogas no Brasil deixou de ser um problema de saúde pública e hoje é o principal elemento propulsor do encarceramento. Mas a validade dessa "guerra" é questionável.

Em pesquisa realizada pela Fiocruz, os dados mais preocupantes não estão relacionados às substâncias ilícitas: o principal problema da população brasileira é o álcool. O estudo também revelou que o fantasma das drogas não é tão prevalecente na sociedade como o discurso midiático e político faz parecer: 3,1\% da população já fizeram uso de cocaína, mas apenas 0,3\% fizeram uso no período de 30 dias que antecedeu a pesquisa (BASTOS, 2017).

Dados do Observatório Brasileiro de Informações sobre Drogas apontam que, em 2007, cerca de 135 mil internações foram realizadas devido a comportamento consequente do uso de drogas. Destas, $69 \%$ foram causadas pelo uso de álcool, mas 


\section{artigos}

\section{Larissa Cabelo de Campos}

apenas 5\% estão relacionadas ao uso de cocaína (DADOS..., 2019).

Os números relativos às drogas ilícitas levantam questionamentos sobre a real necessidade de inaugurar uma ofensiva militar, tão custosa e funesta. Além de ser um propulsor do encarceramento em massa, inflando um sistema em que 30,43\% dos presos não foram sequer julgados (PRESOS..., 2019), a guerra declarada às drogas devido à sua seletividade - "escurece" as celas superlotadas do sistema (WACQUANT, 2007, p. 116).

O impacto deste sistema na sociedade ultrapassa a vida de pessoas que estão atrás de uma grade e atinge sistematicamente a família e o círculo social desses indivíduos: vida escolar e profissional interrompidas, desmantelamento de famílias, retirada forçada da figura paternal e maternal na vida da criança e estigmatização de regiões e indivíduos (WACQUANT, 2007).

Wacquant (2007) afirma que o aprisionamento alimenta a reincidência justamente por interromper tais processos. O desemprego, a marginalização e a pobreza serão presenças constantes até mesmo na vida do egresso. Isso imprime um rótulo em quem o integra, seja direta ou indiretamente.

O que a cadeia produz, na realidade, é a intensificação da marginalização e da exclusão social de classes que já estão à margem, além de alimentar a descrença e a desconfiança nas autoridades, visto que o judiciário opera com pesos diferentes para determinadas classes e etnias.

Além de retirar a responsabilidade do Estado e da sociedade de lidar com os problemas gerados pelo próprio sistema neoliberal, ainda há duas consequências decorrentes desse processo penal: a retroalimentação da criminalidade e o 


\section{artigos}

\section{A continuidade punitiva na História do Brasil}

agravamento do sentimento de insegurança. Ou seja, a prisão impulsiona as desordens que ela propõe combater.

De certa forma, essas consequências não são uma falha, mas sim parte desse projeto, visto que o discurso punitivo parte do encarceramento em massa - vigente nos EUA, mas também identificado no Brasil - é de que os criminosos devem "voltar a sofrer" por conta de suas más escolhas (WACQUANT, 2007).

Paralelo a isso, o sentimento de insegurança é promovido de forma descolada da realidade, em que há um embaralhamento da noção do que é crime e do que é apenas incômodo, e há uma distorção da real insegurança existente (WACQUANT, 2007).

A palavra "segurança", inclusive, sofre mudanças de sentido. Associamos segurança pública automaticamente à questão judiciária, criminal e penal ou, no máximo, em uma prevenção protecionista e voltada ao patrimônio. O que deixamos passar - mas Wacquant (2007) nos lembra - é que a segurança também tem outras frentes que são esquecidas. A segurança de um emprego estável, a segurança da moradia, a segurança da educação de qualidade, a segurança da saúde gratuita.

Essas diversas "frentes" da segurança, que são deixadas em segundo plano e que não são consideradas quando se discute criminalidade, seriam fundamentais para a devida prevenção ao crime, afinal compõem um mesmo universo. Na prática, o encarceramento é utilizado como um "remédio universal" a todos esses "males" gerados pela modernidade.

\section{Conclusão}

Longe de ser apenas um reflexo da influência norte-americana nas políticas 


\section{artigos}

\section{Larissa Cabelo de Campos}

penais brasileiras, o encarceramento em massa como mecanismo de controle tem diversas raízes nacionais inequívocas - que o pensamento punitivista contemporâneo tende a reforçar de distintas maneiras.

A formação do Estado Nacional se deu em um regime escravista que qualificava pessoas como uma ferramenta de trabalho. A "retirada" da humanidade de indivíduos escravizados se torna, então, a base de um sistema calcado na segregação e na exploração humana, além da exclusão social de grupos que não integravam os papeis da sociedade da época, como a classe de brancos pobres não proletarizados. Já durante os períodos autoritários e ditatoriais, os indivíduos considerados "subversivos" foram adicionados aos grupos já marginalizados por meio da perseguição, da tortura, da prisão e da execução.

Há uma continuidade no padrão da política e do pensamento punitivo, ainda que haja transformações devido ao contexto e a época em que cada processo ocorre. A figura do inimigo muda, mas suas características permanecem parecidas, como a etnia e classe social. Para pensar essa questão, é possível olhar para os diversos exemplos de "inimigos eleitos" pela sociedade brasileira: o "vadio", o "comunista" e, na contemporaneidade, o "traficante".

A criminologia do outro, teorizada por Garland (2001), é materializada nas relações sociais constituídas em diversos aspectos da sociedade brasileira. Quando o outro ocupa um lugar diferente, pensamentos estritamente punitivos se consolidam com maior facilidade e a segregação social é desenvolvida de inúmeras maneiras.

Os mais de 700 mil encarcerados no Brasil, com perfil socioeconômico e demográfico característicos, são um reflexo de uma sociedade que não busca solucionar seus profundos problemas sociais e opta por marginalizar os indivíduos 


\section{artigos}

\section{A continuidade punitiva na História do Brasil}

que simbolizam tais problemas - ou até mesmo exterminar sistematicamente grupos sociais.

Algo parecido foi apontado por Wacquant (2007) quando ele afirma que o encarceramento em massa opera de maneira a criminalizar a pobreza e gerir a miséria - fruto da dessocialização do trabalho na era neoliberal. O excedente de trabalhadores que não são absorvidos pelo mercado torna-se, então, um problema que é resolvido com a detenção e exime do Estado as responsabilidades com o apoio social a essa parcela da população.

É possível concluir que o encarceramento em massa no Brasil é constituído de um pensamento punitivo devidamente construído durante a formação da nação e na utilização da violência institucionalizada por diversos setores da sociedade. A imposição do medo e da construção de diferentes "inimigos" foram bases materiais para que o desejo popular por punição desse subsídio a práticas seletivas de controle, parte de uma justiça parcial que têm como alvo indivíduos com cor e classe social determinadas.

Por fim, o encarceramento no País é um instrumento importante na manutenção do neoliberalismo. Para que essa arte de governar - que eleva a individualidade, bem como as responsabilidades individuais sobre as questões coletivas - permaneça em vigor, é preciso um sistema de controle que force grupos a viver à margem da sociedade, além do reforço ideológico da divisão entre indivíduos "merecedores" e "não merecedores". O outro e o eu. 
Larissa Cabelo de Campos

\section{Referências}

BASTOS, Francisco Inácio Pinkusfeld Monteiro et al. (Org.). III Levantamento Nacional sobre o uso de drogas pela população brasileira. Rio de Janeiro: FIOCRUZ/ICICT, 2017. 528 p. Disponível em: <https://www.arca.fiocruz.br/handle/icict/34614>. Acesso em: 20 de setembro de 2019.

BELLI, B. Violência Policial e Segurança Pública: democracia e continuidade autoritária no Brasil contemporâneo. Impulso, Piracicaba, 2004.

. Polícia, "Tolerância Zero" e Exclusão Social. Novos Estudos CEBRAP, n. 58, 2000.

CANCELLI, Elizabeth. O mundo da violência: A Polícia da Era Vargas. 2a . Ed. Brasília, Editora UNB, 1994.

COMISSÃO da Verdade do Estado de São Paulo. Relatório. Tomo I. Parte I: Estruturas e Sistemas da Repressão. Capítulo 7: A Militarização da Segurança Pública. 2015. Disponível em: <http://comissaodaverdade.al.sp.gov.br/relatorio/tomo-i/parte-icap7.html>. Acesso em: 13 jun. 2019.

DADOS e informações gerais sobre drogas. Ministério da Cidadania. 2019. Observatório Brasileiro de Informações sobre drogas. Disponível em: <http://mds.gov.br/obid/dados-e-informacoes-sobre-drogas/populacao-geral>.

Acesso em: 19 de setembro de 2019.

FRANCO, M. S. de C. Homens livres na ordem escravocrata. Unesp, 1997.

GARLAND, D. La Cultura del Control: crimen y orden social em La sociedad contenporánea, Editora Gedisa, Espanã, Barcelona, 2001.

. The meaning of mass imprisonment, in Mass Imprisonment: Social Causes and Consequences. London: Sage, 2001.

GODOI, Rafael. Fluxos em cadeia: as prisões em São Paulo na vidada dos tempos. Tese (Doutorado em Sociologia) - Departamento de Sociologia, FFLCH, Universidade de São Paulo, São Paulo, 2015. https://doi.org/10.11606/t.8.2015.tde-05082015161338

KOERNER, A. Punição, disciplina e pensamento penal no Brasil do século XIX. Lua Nova 2006. 


\section{artigos}

A continuidade punitiva na História do Brasil

MACHADO, M. Crime e escravidão: Trabalho, Luta, Resistência nas lavouras paulistas, 1830-1888. São Paulo: Editora Brasiliense, 1987.

NÚMEROS de presos por tráfico de drogas cresce 508\% em 12 anos no estado de SP. G1, São Paulo, 26 de junho de 2018. Globonews. Disponível em: <https://glo.bo/2E4fn8j>. Acesso em: 19 de agosto de 2019.

PRESOS em unidades prisionais no Brasil. Departamento Penitenciário Nacional. 2019. Disponível em: <https://bit.ly/3kODKIc>. Acesso em: 23 de julho de 2020.

PRESOS provisórios. Departamento Penitenciário Nacional. 2019. Disponível em: <https://bit.ly/3h3ZyNq>. Acesso em: 23 de julho de 2020.

QUANTIDADE de incidência por tipo pena. Departamento Penitenciário Nacional. 2019. Disponível em: <https://bit.ly/3atECNF>. Acesso em: 23 de julho de 2020.

SCHWARCZ, Lilia Moritz. Sobre o autoritarismo brasileiro. Editora Companhia das Letras, 2019.

SERRA, Carlos Henrique Aguiar. Cultura punitiva e sociedade escópica: algumas considerações. In: Simpósio Nacional de História, 26. 2011, São Paulo. Anais [...]. São Paulo: $\quad$ ANPUH, 2011. p. 1-11. Disponível em: <http://www.snh2011.anpuh.org/resources/anais/14/1308138342_ARQUIVO_Culturap unitivaesociedadeescopicaanpuh2011.pdf>. Acesso em: 10 nov. 2020.

SERRA, C. A militarização da segurança pública e as permanências autoritárias:

contradições e perspectivas do Estado de direito. In: Ecos da ditadura na sociedade brasileira (1964-2014) [S.l: S.n.], 2014. Disponível em: <https://www.marilia.unesp.br/Home/Publicacoes/ecos-da-ditadura ebook.pdf> Acesso em: 19 de agosto de 2019.

TEIXEIRA, A. A militarização à brasileira: justiça privatista e gestão dos ilegalismos In: Ecos da ditadura na sociedade brasileira (1964-2014) [S.I: s.n.], 2014. Disponível em: <https://www.marilia.unesp.br/Home/Publicacoes/ecos-da-ditadura_ebook.pdf>. Acesso em: 19 de agosto de 2019.

- Prisões da exceção: Política penal e penitenciária no Brasil contemporâneo. Curitiba: Juruá, 2009.

WACQUANT, L. Rumo à militarização da marginalização urbana. In: Discursos, 


\section{artigos \\ Larissa Cabelo de Campos}

sediciosos, crime, direito e sociedade. Rio de Janeiro: Editora Revan, 2007.

Punir os pobres: a nova gestão da miséria nos Estados Unidos. Rio de Janeiro: Editora Revan, 2007.

. Crafting the Neoliberal State: Workfare, Prisonfare, and Social Insecurity.

Sociological Forum, v. 25, n. 2, p. 198-220, jun. 2010. 